T he journals that are reviewed and the criteria for selecting articles from these journals for inclusion in Evidence-Based Mental Health are set out in the purpose and procedure in each issue. These articles met inclusion criteria for Evidence-Based Mental Health but were not abstracted due to lack of space.

\section{THERAPEUTICS}

Boonstra AM, Kooij JSS, Oosterlaan J, et al. Does methylphenidate improve inhibition and other cognitive abilities in adults with childhood-onset ADHD? J Clin Exp Neuropsychol 2005;27:278-98.

Bradley R, Greene J, Russ E, et al. A multidimensional metaanalysis of psychotherapy for PTSD. Am J Psychiatry 2005;162:214-27.

DeRubeis RJ, Hollon SD, Amsterdam JD, et al. Cognitive therapy vs medications in the treatment of moderate to severe depression. Arch Gen Psychiatry 2005;62:409-16.

Ehlers A, Clark DM, Hackmann A, et al. Cognitive therapy for post-traumatic stress disorder: development and evaluation. Behav Res Ther 2005;43:413-31.

Hollon SD, DeRubeis RJ, Shelton RC, et al. Prevention of relapse following cognitive therapy vs medications in moderate to severe depression. Arch Gen Psychiatry 2005;62:417-22.

Kasper S, Stein DJ, Loft $\mathrm{H}$, et al. Escitalopram in the treatment of social anxiety disorder: randomised, placebocontrolled, flexible-dosage study. $\mathrm{Br} \quad J$ Psychiatry 2005; 186:222-6.

Valmaggia LR, Van der Gaag M, Tarrier N, et al. Cognitivebehavioural therapy for refractory psychotic symptoms of schizophrenia resistant to atypical antipsychotic medication: randomised controlled trial. Br J Psychiatry 2005; 186:324-30.

Wagena EJ, Knipschild P, Zeegers MPA. Should nortriptyline be used as a first-line aid to help smokers quit? Results from a systematic review and meta-analysis. Addiction 2005; 100:317-26.

\section{AETIOLOGY}

Evans J, Heron J, Lewis G, et al. Negative self-schemas and the onset of depression in women: longitudinal study. $\mathrm{Br} \mathrm{J}$ Psychiatry 2005;186:302-7.

Kendler KS, Myers J, Prescott CA. Sex differences in the relationship between social support and risk for major depression: A longitudinal study of opposite-sex twin pairs. Am J Psychiatry 2005;162:250-6.

Li J, Laursen TM, Precht DH, et al. Hospitalization for mental illness among parents after the death of a child. $N$ Engl J Med 2005;352:1190-6.

\section{DIAGNOSIS}

Furlanetto LM, Mendlowicz MV, Bueno JR. The validity of the Beck Depression Inventory-Short Form as a screening and diagnostic instrument for moderate and severe depression in medical inpatients. $J$ Affect Disord 2005;86:87-91.

Borson S, Scanlan JM, Watanabe J, et al. Simplifying detection of cognitive impairment: Comparison of the MiniCog and Mini-Mental State Examination in a multiethnic sample. J Am Geriatr Soc 2005;53:871-4.

\section{PREVALENCE}

Kennedy N, Boydell J, Kalidindi S, et al. Gender differences in incidence and age at onset of mania and bipolar disorder over a 35-year period in Camberwell, England. Am J Psychiatry 2005; 162:257-62.

Oliver MI, Pearson N, Coe N, et al. Help-seeking behaviour in men and women with common mental health problems: cross-sectional study. Br J Psychiatry 2005;186:297-301.

Smalbrugge M, Jongenelis L, Pot AM, et al. Comorbidity of depression and anxiety in nursing home patients. Int $J$ Geriatr Psychiatry 2005;20:218-26.

\title{
11th European Forum on Quality Improvement in Health Care
}

26-28 April 2006, Prague, Czech Republic For further information please go to: www.quality.bmipg.com Book early to benefit from a discounted delegate rate 